\title{
Urogenital Myiasis Caused by Psychoda Albipennis: A Case Report
}

\section{Ürogenital Myiasis: Psychoda Albipennis'in Etken Olduğu Bir Olgu}

\author{
Ersagun Karagüzel1, Ömer Kutlu1, Kurtuluş Buruk2, Ali Ertan Okatan1, Güner Kemal Özgür1 \\ ${ }^{1}$ Karadeniz Technical University Faculty of Medicine, Department of Urology, Trabzon, Turkey \\ 2Karadeniz Technical University Faculty of Medicine, Department of Clinical Microbiology, Trabzon, Turkey
}

\begin{abstract}
Urogenital myiasis is one of the parasitic diseases of the urinary system. We report a case of urogenital myiasis caused by Psychoda albipennis in a 64-year-old male patient. The patient who was admitted to our clinic with the complaints of dysuria and urinary discharge of larvae lasted for a month, brought along the larvae which were examined in the microbiology laboratory. The examination of larvae revealed that they were the fourthstage larvae of the moth fly Psychoda albipennis. The patient, whose physical examination and laboratory investigations were normal, was treated with oral hydration, antiseptic and antibiotics.
\end{abstract}

Keywords

Urogenital myiasis, Psychoda albipennis, larva

\section{ÖZ}

Ürogenital myiasis, üriner sistemin paraziter hastalıklarından birisidir. Bu olguda, 64 yaşında bir erkek hastada Psychoda albipennis adlı bir sinek türünün neden olduğu ürogenital myiasis olgusu sunulmaktadır. Yaklaşık bir aydır idrarında yanma ve zaman zaman idrarından larva benzeri canlılar gelmesi şikayetiyle polikliniğimize başvuran hastanın, yanında getirdiği iki adet larva mikrobiyoloji laboratuvarında incelendi. Bu larvaların Psychoda albipennis adlı sineğin 4. dönem larvaları olduğu tespit edildi. Fizik muayenesinde ve yapılan laboratuvar incelemelerinde herhangi bir patoloji saptanmayan hasta; bol hidrasyon, üriner sistem antiseptiği ve antibiyoterapi ile başarılı bir şekilde tedavi edilmiştir.

\section{Anahtar Kelimeler}

Ürogenital myiasis, Psychoda albipennis, larva

\section{Introduction}

Myiasis is a parasitic disease caused by fly larvae from the order Diptera of the class Insecta in human or animal living or necrotic tissue. One form of myiasis rarely seen in humans is urogenital myiasis. Larvae from various fly species can cause urogenital myiasis $(1,2,3,4)$. One of the rare agents involved in urogenital myiasis is the fly species Psychoda albipennis. Psychoda albipennis adults are 1.5-2 $\mathrm{mm}$ in length and resemble moths in appearance. Larvae deposited by the fly are cylindrical in shape, gray-white in color and short-haired or scaly. The larvae go through 4 developmental stages. The larvae can be deposited in places with rich organic contents, such as garbage or sewage, or else in nutrient-rich wounds in living things (5). This report describes a case of urogenital myiasis caused by Psychoda albipennis.

\section{Case Presentation}

A 64-year-old male patient presented to our clinic with discomfort while urinating over the previous month and occasional larva-like organisms emerging from urine. The patient was born in the Vakfikebir district of Trabzon, Turkey, and lived in the Vakfıkebir town center. He was a retired manual worker with no relationship with farming or animal husbandry. No pathological finding was present at physical examination apart from general lack of hygiene. Laboratory tests including complete urinalysis, urine culture and full blood count were normal. Two larvae from the patient's urine that he had placed in a jar were examined in the Karadeniz Technical University Medical Faculty Microbiology Department, where they were identified as 4 th stage Psychoda albipennis larvae (Figure 1). The patient was given antibiotic and urinary system antiseptic therapy in order to prevent secondary bacterial infection, and plentiful oral hydration was recommended in order to expel any other larvae in the bladder. Complete resolution of symptoms was observed at post-therapeutic follow-up.

\section{Discussion}

Psychoda albipennis, one of the agents of urogenital myiasis in humans, is particularly prevalent in parts of Europe with a temperate

\section{Correspondence}

Ersagun Karagüzel MD, Karadeniz Technical University Faculty of Medicine, Department of Urology, Trabzon, Turkey

Phone: +90 4623775908 E-mail: ersagunkaraguzel@gmail.com Received: 02.04.2015 Accepted: 29.04.2015 


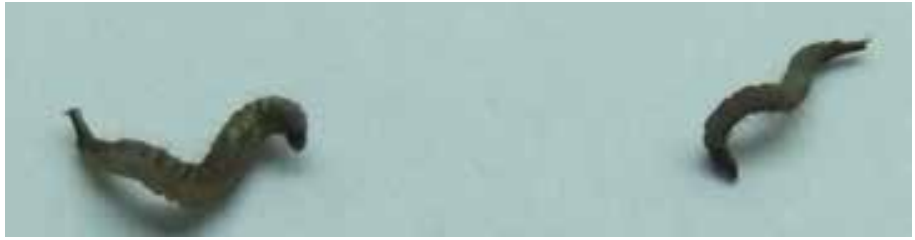

Figure 1. Psychoda albipennis larvae

climate (6). It is found in various regions of Turkey, especially in the provinces of Tekirdağ, Edirne, Ankara, İstanbul, and Bursa (7). Previous cases of urogenital myiasis caused by Psychoda albipennis have been reported in Turkey $(8,9)$.

Flies that cause myiasis are more common in rural regions with widespread animal husbandry. Living in rural areas and working in livestock raising therefore increases the risk. Poor hygiene conditions, close contact with animals and sleeping uncovered in open area are some predisposing factors. The fact that our patient did not work in animal husbandry or farming reduced the potential risk factors. On the other hand, these agents can also be encountered in cities and in regions where general hygiene conditions are poor (7). Our patient lived in a town, and poor general personal hygiene was the only risk factor identified.

Psychoda albipennis adults do not exceed $2 \mathrm{~mm}$ in size. Their bodies are gray-brown and covered in dense hairs. They lay their eggs in groups of 30-40 in dark and humid areas such as toilets and bathrooms. The larvae are found in unclean areas such as garbage cans, sewage water and rotting fruit and vegetables. Urogenital myiasis can develop in humans as a result of flies laying eggs or larvae around the urethral mea. Expelled $4^{\text {th }}$-stage larvae are seen in the urine of infected patients (10). Fourth-stage Psychoda albipennis larvae of the kind detected in urine in our case are gray-white in color, 3-5 mm in size with a flattish appearance. Their bodies are covered in short hairs and scales the sides may sometimes be bordered with tooth-like projections (11).

Symptoms and findings, such as dysuria, pollakiuria, hematuria, urinary system obstruction and hematuria can be seen in patients with urogenital myiasis (12). No such urinary symptoms were present in this case. Myiasis should be treated by removal of larva if these are detected in an open wound anywhere on the body, wound cleaning, antiparasitic drugs and antibiotherapy. In urogenital myiasis, larvae in the urinary system are generally expelled through the mechanical cleansing effect of urine. Plentiful hydration in order to remove all larvae present in the urinary system and urinary system antiseptic and antibiotherapy in order to prevent potential complications are recommended (5).
In conclusion, urogenital myiasis must always be considered when no pathology is identified at examinations in patients presenting with nonspecific urinary system symptoms and with poor general personal hygiene, and the appropriate investigations should be performed. It should also be remembered that the disease may cause no significant urinary symptoms other than occasional larva expelled in urine.

\section{Authorship Contributions}

Informed Consent: Consent form was filled out by all participants. Concept: Güner Kemal Özgür, Design: Ömer Kutlu, Data Collection or Processing: Kurtuluş Buruk, Ersagun Karagüzel, Analysis or Interpretation: Ersagun Karagüzel, Literature Search: Ali Ertan Okatan, Writing: Ersagun Karagüzel, Peer-review: Internal peerreviewed, Conflict of Interest: No conflict of interest was declared by the authors, Financial Disclosure: The authors declared that this study has received no financial support.

\section{References}

1. Abe DK, Rosa RT, Dall'Oglio MF, Fróes MH, Almeida BC, Said LA. Urethral myiasis. Braz J Infect Dis 2009;13:248.

2. Meinhardt W, Disney RH.Urogenital myiasis caused by scuttle fly larvae (Diptera: Phoridae). Br J Urol 1989;64:547.

3. Wadhwa V, Kharbanda P, Rai S, Uppal B. Urogenital myiasis due to Chrysomyia bezziana. Indian J MedMicrobiol 2006;24:70-71.

4. González MM, Comte MG, Monárdez PJ, Díaz de Valdés LM, Matamala $\mathrm{Cl}$. Accidental genital myiasis by Eristalis tenax. Rev Chilena Infectol 2009;26:270.

5. Güven E, Kar S, Doğan N, Karaer Z. Urogenital myiasis caused by Psychoda albipennis in woman. Türkiye Parazitol Derg 2008;32:174-176.

6. Zumpt F. Myiasis in man and animals in the old World: a text book for Physicians, Veterinarins and Zoologists. Butter worth and Co Ltd, London, 1965:267.

7. Merdivenci A. Türkiye parazitleri ve parazitoloji yayınları. Cerrahpaşa Tıp Fakültesi Yayınları, İstanbul, 1970:322-340.

8. Yenice MG, Demir T, Babür C, Nalbantoğlu S, Kılıç S. Psychoda albipennis'in (Diptera: Nematocera) neden olduğu ürogenital miyazis olgusu. Mikrobiyol Bül 2011;45:558-564.

9. Taylan-Ozkan A, Babur C, Kilic S, Nalbantoglu S, Dalkilic I, Mumcuoglu KY. Urogenital myiasis caused by Psychoda albipennis (Diptera: Nematocera) in Turkey. Int J Dermatol 2004;43:904-905.

10. Dinçer Ş. Insan ve hayvanlarda myiasis. Özcel MA, Daldal N (eds). Artropod Hastalıkları ve vektörler. Türkiye Parazitoloji Derneği Yayını, İzmir, 1997;169-233.

11. John DT, Petri WA. Markell and Voge's Medical Parasitology. 9th ed. Saunders, Elsevier, Missouri, 2006;328-334.

12. Mumcuoglu I, Akarsu GA, Balaban N, Keles I. Eristalis tenax as a cause of urinary myiasis. Scand J InfectDis 2005;37:942-943. 